\title{
FAKTOR-FAKTOR PENYEBAB KEKAMBUHAN PADA \\ PASIEN SKIZOFRENIA DI POLIKLINIK JIWA \\ RSUD H. ANDI SULTHAN DG. RADJA \\ KABUPATEN BULUKUMBA
}

\author{
${ }^{1}$ Edison Siringoringo \\ ${ }^{2}$ Haerati
}

\footnotetext{
${ }^{1}$ Program Studi S1 Keperawatan, Stikes Panrita Husada Bulukumba

${ }^{2}$ Program Studi S1 Keperawatan, Stikes Panrita Husada Bulukumba
}

\author{
Alamat Korespondensi: \\ Ns.Edison Siringoringo, S.Kep \\ Program Studi Ilmu Keperawatan \\ Sekolah Tinggi Ilmu Kesehatan Panrita Husada \\ Bulukumba, 23372 \\ HP: 085236933338 \\ Email: edi.siringoringo@gmail.com
}




\begin{abstract}
Abstrak
Skizofrenia merupakan seseorang yang memiliki masalah kejiwaan, atau kepribadian yang terganggu seperti pikiran, perasaan, pendengaran, emosi, bahasa, delusi, serta perilaku yang tidak sesuai sebagaimana manusia normal lainnya. Alasan Apabila penyakit ini tidak ditangani maka akan menimbulkan dampak yang merugikan dan membahayakan pasien, keluarga, dan masyarakat karena dapat berperilaku seperti mengamuk, bertindak sesukanya, menghancukan barang-barang atau pasien akan melukai orang lain bahkan diri sendiri. Faktor-faktor yang diteliti yaitu dukungan keluarga, usia, dan kepatuhan minum obat. Tujuan penelitian ini untuk mengetahui Faktor-Faktor Penyebab Kekambuhan Pada Pasien Skizofrenia diPoliklinik Jiwa RSUD H.Andi Sulthan Dg. Radja Kabupaten Bulukumba. Desain penelitian menggunakan desain Analitik dengan pendekatan cross sectional. Populasi dalam penelitian adalah semua pasien skizofrenia yang mengalami penyakit skizofrenia disertai keluarga selama 1 bulan di poliklinik jiwa RSUD H. Andi Sulthan Dg. Radja Bulukumba didapatkan data dari januari-maret sebanyak 135 orang, dengan tekhnik pengambilan sampel menggunakan non probability sampling. Jumlah sampel dalam penelitian ini sebanyak 57 responden. Data diperoleh melalui lembar kuesioner yang dibuat oleh peneliti kepada responden. Analisa data menggunakan Uji Chis-quare alternatif Fisher dan Uji Kolmogorov-Smirnov tes, dengan taraf kemaknaan $\alpha=0,05$. Hasil analisa data menunjukkan variabel umur $p=0,032$, dukungan keluarga $p=0,005$, dan variabel kepatuhan minum obat $p=0,025$. Kesimpulan bahwa terdapat hubungan antara umur, dukungan keluarga, kepatuhan minum obat terhadap kekambuhan penyakit skizofrenia di poliklinik jiwa RSUD H. Andi Sulthan Dg. Radja di Kabupaten Bulukumba tahun 2018.Saran diharapkan Penelitian ini dapat dijadikan sebagai tambahan pengetahuan untuk mengurangi frekuensi kekambuhan pasien skizofrenia.
\end{abstract}

\title{
Kata Kunci: Umur, Dukungan Keluarga, Kepatuhan Minum Obat, Kekambuhan
}

\begin{abstract}
Schizophrenia is a person who has a psychiatric problem, or a disturbed personality such as thoughts, feelings, hearing, emotions, language, delusions, and behavior that is not in accordance with other normal humans. Reason If the disease is not treated it will cause adverse effects and endanger the patient, family, and society because they can behave like a tantrum, act as they please, destroying goods or patients will hurt others even themselves. Factors studied were family support, age, and adherence to taking medication. The purpose of this study was to determine the factors that cause recurrence in schizophrenic patients in the Catholic Clinic of H.Andi Sulthan Hospital Dg. Radja Regency of Bulukumba. The research design uses analytical design with cross sectional approach. The population in the study were all schizophrenic patients who had schizophrenia accompanied by a family for 1 month at the mental clinic of H. Andi Sulthan Hospital Dg. Radja Bulukumba obtained data from January-March as many as 135 people, with sampling techniques using non-probability sampling. The number of samples in this study were 57 respondents. Data obtained through questionnaires made by researchers to respondents. Data analysis using Fisher's alternative Chis-quare test and KolmogorovSmirnov test, with a significance level of $\alpha=0.05$. The results of data analysis showed age variables $p=0.032$, family support $p=0.005$, and medication adherence variables $p=0.025$. Conclusion that there is a relationship between age, family support, medication adherence to the recurrence of schizophrenia in the mental clinic of H. Andi Sulthan Hospital Dg. Radja in Bulukumba District in 2018. Suggestion expected This research can be used as additional knowledge to reduce the frequency of recurrence of schizophrenic patients.
\end{abstract}

Keywords: Age, Family Support, Drug Adherence, Recurrence 
PENDAHULUAN

Kesehatan Jiwa yang dialami penduduk di dunia dan terus mengalami peningkatan yaitu dari penduduk yang menderita kelainan jiwa dari rasa stress, cemas, depresi, pengunaan obat, kenakalan remaja, sampai skizofrenia. Dari banyaknya gangguan jiwa ada salah satu gangguan jiwa terberat yaitu skizofrenia (Arianti, Novera, \& Rosa, 2017).

Skizofrenia yaitu seseorang yang memiliki masalah kejiwaan, atau kepribadian yang terganggu seperti pikiran, perasaan, pendengaran, emosi, bahasa, delusi, serta perilaku yang tidak sesuai sebagaimana manusia normal lainnya (Prabowo, 2014). Faktor-faktor yang mempengaruhi kambuhnya penyakit skizofrenia yang diteliti yaitu dari faktor dukungan keluarga, usia, dan faktor kepatuhan minum obat. Alasan Apabila penyakit ini tidak di tangani maka akan menimbulkan dampak yang akan merugikan dan membahayakan pasien, keluarga, dan masyarakat karena dapat berperilaku menyimpang misalnya: mengamuk, bertindak sesukanya, menghancukan barang-barang atau pasien akan melukai orang lain bahkan diri sendiri (Kurnia, Tyaswati, \& Abrori, 2015).
Menurut World Health Organization (WHO) menyebutkan bahwa Skizofrenia adalah gangguan mental berat yang mempengaruhi lebih dari 21 juta orang di seluruh dunia diperkirakan $4,4 \%$ dari populasi global menderita gangguan depresi, dan 3,6\% mengalami gangguan kecemasan. Jumlah penderita depresi meningkat lebih dari $18 \%$ antara tahun 2005 dan 2015 (WHO, 2017).

Menurut (Depkes RI, 2013) prevalensi gangguan jiwa berat, seperti skizofrenia adalah 1,7 per 1000 penduduk atau sekitar 400.000 orang. Dari jumlah tersebut, ternyata $14,3 \%$ di antaranya sekitar 57.000 orang pernah atau sedang dipasung. Pemasungan di pedesaan sebesar 18,2\%. Angka ini lebih tinggi jika di bandingkan pada angka di perkotaan, yaitu sebesar $10,7 \%$

Berdasarkan data Riset Kesehatan Dasar (Riskesda, 2013).Prevalensi gangguan jiwa berat di Indonesia 1,7 per mil. Gangguan jiwa berat terbanyak di Yogyakarta, Aceh, Sulawesi Selatan, Bali, dan Jawa Tengah. Proporsi RT (Rumah Tangga) yang pernah memasung gangguan jiwa berat 14,3 persen dan terbanyak pada penduduk yang tinggal di pedesaan $(18,2 \%)$, serta pada kelompok penduduk dengan kuintil indeks kepemilikan terbawah $(19,5 \%)$. Prevalensi penderita 
Skizofrenia di indonesia sebanyak 0,3 sampai $1 \%$ dan biasanya timbul pada usia sekitar 18 tahun - 45 tahun, namu terdapat juga pada usia 11 tahun - 12 tahun sudah menderita penyakit skizofrenia

\section{Dari data (Provinsi Sulawesi} Selatan tahun 2013) ditemukan gangguan jiwa berat 2,6 dan gangguan mental sekitar 16.517 orang. Pasien di diagnosa keperawatan yaitu Halusinasi sekitar 7.604 orang, menarik diri 2.705 orang, waham 833 orang, harga diri rendah 1.771 orang, perilaku kekerasan 1.304 orang, defisit care 2.235 orang, percobaan bunuh diri 59 orang (Ali, 2014).

Data awal di RSUD H. Andi Sulthan Dg. Radja Bulukumba yang memeriksakan kesehatan pada tahun 2015 sampai 2016. Pada tahun 2015 berjumlah 495 orang dan tahun 2016 sebanyak 499 orang dan di tahun 2017 meningkat kembali sebanyak 682 orang. Di dapatkan pula data di tahun 2018 pada bulan Januari sebanyak 38 orang, bulan februari sebanyak 43 orang, dan pada bulan maret sebanyak 54 orang.

Kekambuhan pasien biasanya terjadi karena berbagai yaitu faktor terapi, faktor sistem kesehatan, pendidikan, faktor lingkungan, usia, dukungan keluarga, pengetahuan, kepatuhan minum obat dan sosial ekonomi.jika keluarga tidak siap dan kurang memiliki informasi yang memadai untuk melakukan penyesuaianpenyesuaian yang cukup besar dengan kehadiran anggota keluarga yang mengalami skizofrenia maka dapat menyebabkan timbulnya kekambuhan kembali. Dari semua faktor yang menyebabkan kekambuhan, diperlukan komitmen yang kuat dan koordinasi yang erat dari seluruh pihak dalam mengembangkan pendekatan multidisiplin untuk menyelesaikan permasalahan (Yuliantika, Jumaini, \& Sabrianan, 2012). Umur merupakan Lamanya kehidupan seseorang atau suatu karakteristik yang melekat pada setiap individu dan dari awal kelahiran sampai pada saat penelitian ini dilakukan di poliklinik jiwa RSUD. H. Andi Sulthan Dg. Radja Bulukumba. Diukur selama hidup dalam setahun dan akan meningkat disetiap tahunnya.

Dari hasil penelitian ini di dukung oleh beberapa penelitian yang dilakukan oleh (Kurnia, Tyaswati, \& Abrori, Faktorfaktor yang Mempengaruhi Kekambuhan pada Pasien Skizofrenia di RSD dr. Soebandi Jember, 2015) yang berjudul Faktor-faktor yang Mempengaruhi Kekambuhan pada Pasien Skizofrenia di RSUD dr. Soebandi Jember. Sampel dalam penelitian ini adalah sebanyak 47pasien. 
Hasil analisis menunjukkan bahwa faktor usia teradinya kekambuhan dalam kelompok umur 26-45 tahun sebanyak58 pasien $(53,2 \%)$. Hasil penelitian di temukan beberapa faktor yang bermakna salah satunya adalah usia $(p=0,029)$. Sehingga dapat dikatakan bahwa ada hubungan antara faktor usia dengan kekambuhan pada pasien skizofrenia.

Dukungan keluarga adalah sikap, tindakan, dan penerimaan keluarga terhadap penderita yang sakit, anggota keluarga memandang bahwa orang yang bersifat mendukung selalu siap memberikan pertolongan dan bantuan jika di perlukan (Nadeak \& Arif, 2010).

Hal ini didukung oleh penelitian terdahulu yang dilakukan oleh (Sari, 2017) yang berjudul Dukungan Keluarga Dengan Kekambuhan Pada Pasien Skizofrenia.Sampel dalam penelitian ini adalah sebanyak 70pasien. Hasil analisa univariat menunjukkan bahwa $(50,0 \%)$ keluarga responden menunjukan dukungan keluarga tinggi, $(48,6 \%)$ pasien jarang mengalami kekambuhan. Hasil penelitian ini menunjukkan terdapat hubungan yang bermakna antara dukungan keluarga dengan kekambuhan pasien skizofrenia.

Kepatuhan minum obat merupakan keteraturan penderita dalam meminum obat yang disarankan oleh dokter terhadap pengobatan yang telah di tentukan serta menyelesaikan pengobatan secara teratur dan lengkap tanpa terputus dalam waktu yang telah di tentukan kepada pasien (Raharjo, Rochmawati, \& Purnomo, 2014).

Hal ini didukung oleh penelitian terdahulu yang dilakukan oleh(Maharani \& Hardisal, 2017)yang berjudulfaktor yang berhubungan dengan kekambuhan penderitaskizofrenia di Rumah Sakit Jiwa Tampan Provinsi Riau. Sampel dalam penelitianiniadalahkeluarga pasien yang menderita skizofrenia sebanyak 100 responden.Hasil analisa univariatdan bivariate menujukan sebagian besar kekambuhan pada penderita skizofrenia $\begin{array}{llll}\text { sebanyak } & 61 & (61 \%), & \text { dan }\end{array}$ penderita skizofrenia yang tidak patuh minum obat sebanyak $62(62 \%)$. Hasil penelitian ini menunjukkan terdapat hubungan yang bermakna antara kepatuhan minum obat dan beberapa faktor lainnya terhadap kekambuhan penyakit skizofrenia.

Tujuan penelitian ini adalah untuk mengetahui Faktor-Faktor Penyebab Kekambuhan Pada Pasien Skizofrenia diPoliklinik Jiwa RSUD H.Andi Sulthan Dg. Radja Kabupaten Bulukumba Tahun 2018 . 


\section{METODE}

Jenis penelitian ini merupakan penelitian Kuantitatif menggunakan desain Analitik dengan menggunakan pendekatan Cross Sectional yang(Hidayat, 2014).yang bertujuan untuk mengetahui faktor-faktor penyebab kekambuhan pada pasien skizofrenia dipoliklinik Jiwa RSUD H.Andi Sulthan Dg. Radja Kabupaten Bulukumba Tahun 2018.

$$
\text { Populasi adalah wilayah }
$$
generalisasi yang terdiri atas objek/subjek yang mempunyai kuantitas dan karakteristik tertentu yang ditetapkan oleh peneliti untuk dipelajari dan kemudian ditarik kesimpulannya (Sugiyono, 2012).Populasi dalam penelitian ini adalah Populasi dalam penelitian ini adalah semua pasien skizofrenia yang mengalami kekambuhan di sertai keluarga selama 1 bulan di poli jiwa RSUD. H. Andi Sulthan Dg. Radja Bulukumba di dapatkan data dari Januari-Maret sebanyak 135 orang pada tahun 2018 .

Pengambilan sampel dalam penelitian ini menggunakan non probability sampling adalah penarikan sampel secara tidak acak, dengan teknik pengambilan sampel yaitu quota sampling adalah sampel yang akan diambil ditentukan oleh pengumpul data dan sebelumnya telah ditentukan jumlah yang akan diambil. Kalau umlah tersebut tercapai, maka si pengumpul data berhenti, selanjutnya hasil itu dipresentasekan (Sumantri, 2011).Sampel dalam penelitian ini yaitu sebanyak 57 responden yang didapatkan berdasarkan dengan rumus pengambilan sampel menurut (Setiadi, 2013).

Instrumen dalam penelitian ini adalah kuesioner (angket) . Koesioner digunakan untuk mengumpulkan data tentang umur, dukungan keluarga, kepatuhan minum obat, dan kekambuhan.

Data dianalisis berdasarkan skala ukur dan tujuan penelitian dengan menggunakan perangkat lunak program komputerisasi.Data dianalisis secara : (1). Analisis Univariat, Analisis dilakukan untuk melihat proporsi. (2). Analisis Bivariat, Uji bivariat dilakukan untuk mencari hubungan antara variabel independen dan variabel dependen dengan uji yang digunakan adalah chi-square bila memenuhi syarat, dan akan dilakukan uji fisher's exact sebagai alternative. Kemaknaan yang diterima apabila $\mathrm{p}<0,05$ dan Uji Kolmogorov-Smirnov tes.

\section{HASIL}

$$
\text { Berdasarkan (Tabel 1) }
$$

menunjukkan sebagian besar responden berjenis kelamin laki-laki sebanyak 40 
orang (70.2\%), paling banyak umur responden berada pada kategori Lansia sebanyak 26 orang $(43,4 \%)$, paling banyak responden berpendidikan dasar berjumlah 34 orang $(59.6 \%)$, sebagian besar pekerjaan responden adalah petani berjumlah 35 orang $(61,4 \%)$.

Berdasarkan (Tabel menunjukkan distribusi frekuensi responden berdasarkan umur, dukungan keluarga, kepatuhan minum obat, dengan kekambuhan pada pasien skizofrenia.

Distribusi frekuensi umur sebagian besar memiliki umur tinggi pada lansia sebanyak 26 orang $(45,6 \%)$, sedangkan paling sedikit pada responden yang remaja sebanyak 9 oramg (15.8\%). Keluarga tidak mendukungan sebagian besar memiliki sebanyak 34 orang (59.6\%), sedangkan paling sedikit pada responden yang memiliki keluarga yang mendukung sebanyak 23 orang $(40,4 \%)$. kepatuhanminum obat sebagian besar responden memiliki tidak patuh sebanyak 35 orang $(61.4 \%)$, sedangkan paling sedikit pada responden yang memiliki patuh minum obat yang kurang baik sebanyak 22 orang (38.6\%). Dan kekambuhan sebagian besar yang mengalami kekambuhan sebanyak 49 orang $(86.0 \%)$, sedangkan paling sedikit pada responden yang tidak kambuh sebanyak 8 orang (14.0\%).

Berdasarkan (Tabel

menunjukkan hubungan umur dengan kekambuhan pada pasien skizofrenia dimana responden yang memiliki lansia tinggi lebih banyak yang kambuh sebanyak 26 orang $(100,0 \%)$ lebih besar dibandingkan dengan responden yang memiliki remaja yang mengalami kekambuhan sebanyak 4 orang $(44,4 \%)$. Hasil ujiTwo-Simple Kolmogorov-Smirnov Testdengan tingkat kepercayaan $(\alpha=0.05)$, berdasarkan hasil uji ini didapatkan nilai $p$ $<\alpha(0.032<0.05)$ maka Ho ditolak dan Ha diterima. Hal ini membuktikan bahwa ada hubungan antara umur dengan kekambuhan pada pasien skizofrenia dapat disimpulkan bahwa ada hubungan yang bermakna antara umur dengan kekambuhan pada pasien skizofrenia.

Hubungan dukungan keluarga dengan kekambuhandimana responden yang memiliki keluarga yang tidak mendukung yang banyak mengalami kekambuhan sebanyak 33 responden $(97,1 \%)$ lebih besar dibandingkan dengan responden yang memiliki keluarga yang mendukung dengan kekambuhanpasien skizofrenia berjumlah 16 responden $(69,6 \%)$. Hasil uji Chi-Square alternatifuji fisher dengan tingkat kepercayaan ( $\alpha=$ 
0.05), berdasarkan hasil uji ini didapatkan nilai $p<\alpha(0.005<0.05)$ maka Ho ditolak dan Ha diterima. Hal ini membuktikan bahwaada hubungan antara dukungan keluarga dengan kekambuhan pada pasien skizofrenia

Hubungan kepatuhan minum obat dengan kekambuhan pasien skizofrenia dimana responden yang tidak patuh mengalami kekambuhan yaitu sebanyak 43 responden (91,5\%) lebih besar dibandingkan dengan responden yang patuh mengalami kekambuhan sebanyak 6 responden (60,0\%). Hasil uji ChiSquarealternatif Fisher didapatkan tingkat kepercayaan $(\alpha=0.05)$, berdasarkan hasil uji ini didapatkan nilai $p<\alpha(0.025<0.05)$ maka Ho ditolak dan Ha diterima. Hal ini membuktikan bahwaada hubungan antara kepatuhan minum obat dengan kekambuhan pada pasien skizofrenia.

\section{PEMBAHASAN}

Pada penelitian ini terlihat bahwa terdapat hubungan yang bermakna antara umur, dukungan keluarga, dan kepatuhan minum obat dengan kekambuhan pada pasien skizofrenia di Poliklinik Jiwa RSUD H. Andi Sulthan Dg. Radja di Kabupaten Bulukumbatahun 2018.

Dari hasil uji uji Two-Simple Kolmogorov-Smirnov Testdengan tingkat kepercayaan ( $\alpha=0.05)$,berdasarkan hasil uji ini didapatkan nilai $p<\alpha(0.032<0.05)$ maka Ho ditolak dan Ha diterima. Hal ini membuktikan bahwa ada hubungan antara umur dengan kekambuhan pada pasien skizofrenia. Hal ini sejalan dengan hasil penelitian ( Kurnia, Tyaswati, \& Abrori, 2015) Hasil uji chi square, di temukan beberapa faktor yang bermakna salah satunya adalah usia $(\mathrm{p}=0,029)$. Sehingga dapat dikatakan bahwa ada hubungan antara faktor usia dengan kekambuhan pada pasien skizofrenia.

Adapun asumsi peneliti terkait dengan hasil penelitian bahwa ditemukan jumlah responden yang memiliki umur lansia yang mengalami kekambuhan lebih banyak dibandingkan dengan umur pada remaja. Hal ini terjadi karena pada usia pada tahap dewasa sampai lansia manusia mulai menerima dan memikul tanggungjawab yang berat sehingga dapat menjadi faktor risiko terjadinya kekambuhan. Serta banyaknya masalah kehidupan dalam keluarga seperti kasus perceraian serta tidak terpenuhinya kebutuhan pasien di karenakan keterbatasan finansial dan rasa tidak percaya yang dimiliki oleh keluarga yang biasa menganggap pasien berbeda dan tidak mampu bersosialisasi seperti orang pada umumnya serta terjadinya perubahan 
peran yang dapat menyebabkan stress psikososial, stres dapat terjadi dengan adanya perubahan peran pada pasangan atau keluarga.

Dari hasil uji Chi-Square alternatif Fisher didapatkan nilai $p<\alpha(0.005<0.05)$ maka Ho ditolak dan Ha diterima. Hal ini membuktikan bahwaada hubungan antara dukungan keluarga dengan kekambuhan pada pasien skizofrenia. Hal ini sejalan dengan penelitian (Sari, 2017)uji chisquare. Hasil analisa univariat menunjukkan bahwa $(50,0 \%)$ keluarga responden menunjukan dukungan keluarga tinggi, $(48,6 \%)$ pasien jarang mengalami kekambuhan. Pada analisa bivariat $\mathrm{p}$ value $=0,002$ berarti terdapat hubungan dukungan keluarga dengan kekambuhan pasien skizofrenia.

Adapun asumsi peneliti terkait dengan hasil penelitian bahwa ditemukan jumlah responden yang memiliki dukungan keluarga yang tidak mendukung lebih banyak dibandingkan dengan responden yang memiliki keluarga yang mendukung. Hal ini terjadi karena dukungan emosional, dukungan pengharapan dan dukungan yang nyata dari keluarga yang kurang. Keterbatasan ekonomi terkadang juga membuat keluarga tidak mampu untuk membelikan obat secara terus-menerusagar pasien betul-betul puliah dari penyakitnya. Selain itu keluarga juga berperan dalam menentukan cara atau asuhan keperawatan yang diperlukan pada penderita skizofrenia di rumah, maka dari itu diharapkan keluarga harus memiliki pengetahuan yang tinggi tentang dukungan keluarga agar bisa mendukung kesembuhan pasien dan tidak terjadi kekambuhan yang berulang pada pasien skizofrenia.

Dari hasil uji Chi-Square alternatif Fisher didapatkan nilai $p<\alpha(0.025<0.05)$ maka Ho ditolak dan Ha diterima. Hal ini membuktikan bahwaada hubungan antara kepatuhan minum obat dengan kekambuhan pada pasien skizofrenia. Hal ini sejalan dengan hasil penelitian( Kaunang , Kanine , \& Kallo , 2015)Hasil penelitian menunjukkan terdapat hubungan antara kepatuhan minum obat dengan prevalensi kekambuhan pasien skizofrenia. Dengan diperoleh hasil nilai $(\rho=0,000)$ kurang dari nilai $(\alpha=0,05)$.

Adapun asumsi peneliti terkait dengan hasil penelitian bahwa ditemukan jumlah responden yang patuh minum obat lebih sedikit yang mengalami kambuh dibandingkan dengan responden yang tidak patuh didapatkan lebih banyak yang mengalamikekambuhan. Hal ini berarti dengan pengobatan yang tertaur dan dukungan dari keluarga, masyarakat dan 
orang disekitar klien besar kemungkinan klien dapat bersosialisasi dan memiliki aktivitas seperti orang normal, dengan demikian maka prevalensi kekambuhan pasien dapat berkurang ataupun pasien tidak akan kambuh karena proses pengobatan pasien dilakukan sesuai dengan anjuran dan petunjuk dokter, sehingga kepatuhan pasien minum obat baik, dan prevalensi kekambuhan pasien berkurang bahkan tidak pernah kambuh dalam kurun waktu 1-2 tahun. Kurangnya kepatuhan minum obat dapat pula disebabkan karena beragamnya obat yang diberikan terkadang pasien lebih dulu merasakan efek obat terhadap penyakitnya sehingga pasien menghentikan pengobatannya.Pasien skizofrenia yang menjalani program terapi yang lama dan tidak menghasilkan kesembuhan maka dari itu pasien lebih cenderum menjadi putus asa dan tidak melanjutkan program terapi yang di jalaninya.

\section{KESIMPULAN DAN SARAN}

Berdasarkan hasil penelitian diatas maka disimpulkan bahwa terdapat hubungan yang bermakna antaraumur, dukungan keluarga, kepatuhan minum obat terhadap kekambuhan penyakit skizofrenia di poliklinik jiwa RSUD H. Andi Sulthan Dg. Radja di Kabupaten Bulukumba tahun
2018. Hasil penelitian ini diharapkan dapat memberikan informasi serta dapat digunakan sebagai pedoman agar terus memberikan promosi kesehatan dan meningkatkan program kerja yang berkaitan dengan factor-faktor penyebab kekambuhan pada pasien skizofrenia yang dapat digunakan untuk lebih meningkatkan pengetahuan dan kesadaran masyarakat. Bagi peneliti selanjutnya, hasil penelitian ini dapat dijadikan sebagai data atau informasi dasar untuk melaksanakan penelitian lebih lanjut dengan menggunakan metodologi yang berbeda. Untuk mendapatkan hasil lebih mendalam dapat menggunakan metode penelitian kualitatif, misalnya untuk mengkaji lebih dalam.Untuk penelitian kuantitatif dengan jumlah sampel yang lebih banyak.

\section{DAFTAR PUSTAKA}

Ali, M. (2014). "Analisis faktor yang berhubungan dengan Kekambuhan pasien gangguan jiwa di rumah sakit khususdaerah provinsi sulawesi selatan".Fakultas Ilmu KesehatanUIN Alauddin Makassar: Makassar.

Arianti, d., Novera, m., \& Rosa, a. y. (2017).Hubungan pola asuh keluarga dengan kekambuhan 
pasien skizofrenia di rsj. $h b$. sa'anin padang tahun 2017. Jurnal ilmu kesehatan (jik).

Astuti, a. p., Susilo, t., \& Adiatma Putra, s. m. (2017).Hubungan kepatuhan minum obat dengan periode kekambuhan pada pasien skizofrenia: halusinasi di rumah sakit jiwa prof. $d r$. soeroyo magelang. Cendekia Utama jurnal keperawatan dan kesehatan masyarakat stikes cendekia utama kudus.

F. r., m. Rattu, a., \& Posangi, j. (2017).Faktor-faktor yang berhubungan dengan kepatuhan minum obat pada penderita skizofrenia di rumah sakit jiwa prof. $d r . \quad v . \quad$ l. ratumbuysang provinsi sulawesi utara.

Farkhah, 1., Suryani, \& Hernawati, t. (2017).Faktor caregiver dan kekambuhan klien skizofrenia.jkp volume 5 nomor 1 april 2017.

Febstyo, a. (2017).Skizofrenia dapat pulih dengan pengobata seumur hidup. http://www.google.co.id/amp/s/ww w.arah.com/amp.artikel/23653/skiz ofrenia-dapat-pulih-denganpengobatan-seumur-hidup.html.
Handayani, 1., \& Nurwidawati, d. (2013).Hubungan pola asuh dan ekspresi emosi keluarga dengan kekambuhan pasien skizofrenia di rumah sakit jiwa menur surabaya. jurnal psikologi teori \& terapan.

Hermiati, d., \& Harahap, r. m. (2018).Faktor yang berhubungan dengan kasus skizofrenia pada pasien rawat inap rumah sakit khusus jiwa soeprapto provinsi bengkulu.Jurnal keperawatan silampari (jks).

Hidayat, a. a. (2014).Metode penelitian keperawatan dan teknik analisis data.Jakarta: Salemba Medika.

Hidayat, m. w. (2014).Pasien masalah kejiwaan (skizofrenia).Jawa Barat: Tempo

Idris, m., \& Nurwasilah, s. (2016).Hubungan dukungan keluarga dengan tingkat kekambuhan pada pasien skizofrenia di poliklinik psikiatri rumah sakit jiwa islam klender jakarta timur. dukungankeluarga, tingkat kekambuhan, skizofrenia.

Kaunang, i., Kanine, e., \& Kallo, v. (2015). Hubungan kepatuhan minum obat dengan prevalensi 
kekambuhan pada pasien

skizofrenia yang berobat jalan di ruang poliklinik jiwa rumah sakit prof $d r . \quad v . \quad l$. ratumbuysang manado. ejournal keperawatan (e$\mathrm{kp).}$

Kurnia, f. y., Tyaswati, j. e., \& Abrori, c. (2015). Faktor-faktor yang mempengaruhi kekambuhan pada pasien skizofrenia di rsd $d r$. soebandi jember. kurnia, et al, ejurnal pustaka kesehatan, vol. 3.

Kusumawati, f., \& Hartono, y.

(2010).Buku ajar keperawatan jiwa. Jakarta: SalembaMedika.

Lukluk a., z., \& Bandiyah, s. (2011).Psikologi kesehatan.Yogyakarta: Nuha Medika.

Maharani, r., \& Hardisal. (2017).Faktor yang berhubungan dengan kekambuhan penderita skizofrenia di rumah sakit jiwa tampan provinsi riau. menara ilmu.

Maratining, a., Dayrit, m. w., \& Baradero, m. (2016).Kesehatan mental psikiatri: seri asuhan keperawatan.Jakarta: Kedokteran ECG.

Moskowitz, a. (2011). Schizophrenia, trauma, dissociation, and scientific revolutions', journal of trauma \& dissociation,. Taylor \&Francis Group,: LLC.

Mubin, m. f. (2015).Faktor risiko kekambuhan pada pasien skizofrenia paranoid. jurnal keperawatan jiwa.

Naafi, a. m., Perwitasari, d. a., \& Darmawan, e. (2016).Kepatuhan minum obat pasien rawat jalan skizofrenia di rumah sakit jiwa prof. dr. Soerojo Magelang. kartika-jurnal ilmiah farmasi.

Noviria, m., Triyoso, \& Yanti, 1. (2014).Hubungan dukungan keluarga dengan kunjungan kontrolpasien jiwa skizofrenia di rawat jalan di rsj provinsi lampung.jurnal kesehatan holistik.

Pardede, j. a., Sirait, d., Riandi, r., Emanuel, p., \& Laia, r. (2016).Ekspresi emosi keluarga dengan frekuensi kekambuhan pasien skizofrenia. idea nursing journal.

Perwitasari, d. a. (2008).Kajian penggunaan atypical antipsychotic dan conventional antipsychotic pada pasien skizofrenia di rs. grhasia yogyakarta.Yogyakarta: EGC. 
Pieter, h. z., \& Lubis, n. 1. (2010).Pengantar psikologi dalam keperawatan. Jakarta: Kencana Prenada Media Group.

Prabowo, e. (2014). Buku ajar keperawatan jiwa. yogyakarta: nuha medika.

Raharjo, a. b., Rochmawati, d. h., \& Purnomo. (2014).Faktor-faktor yang mempengaruhi kekambuhan pada pasien skizofrenia di rsjd dr.amino gondohutomo semarang. jurnal ilmu keperawatan dan kebidanan (jikk).

Rasmun, Sukamto, e., \& Piyanti, 1. (2013).Faktor-faktor penyebab kekambuhan pada pasien skizofrenia. Jurnal husada mahakam.

Rawa, f., Rattu, a. m., \& Posangi, j. (2017).Faktor-faktor yang berhubungan dengan kepatuhan minum obat pada penderita skizofrenia di rumah sakit jiwa prof. dr. v. l. ratumbuysang provinsi sulawesi utara.

Riskesda. (2013). Riset kesehatan dasar badan penelitian dan pengembangan

kesehatan

kementerian kesehatan ri. Jakarta

Ronald. (2016).Kepatuhan konsumsi obat, pengetahuan dan dukungan keluarga terhadap frekuensi kekambuhan penderita skizofrenia di desa sriharjo, imogiri, bantul. jurnal kesehatan masyarakat.

Saputra, m. h., Marwansyah, \& Rachmadi, a. (2016).Gambaran dukungan sosial keluarga dalam mencegah kekambuhan pasien skizofrenia di poliklinik jiwa rumah sakit jiwa daerah sambang lihum banjarmasin. poltekkes kemenkes jurusan keperawatan http://ejurnalcitrakeperawatan.com.

Sari, f. s. (2017).Dukunga keluarga dengan kekambuhan pada pasien skizofrenia. jurnal pembagunan nagari.

Sari, h., \& fina, f. (2011).Dukungan keluarga dalam mencegah kekambuhan pasien skizofrenia di poliklinik rawat jalan rsj aceh. idea nursing journal.

Stuart, g. w. (2007).Buku saku keperawatan jiwa.Jakarta: EGC.

Setiadi. (2013).Konsep dan praktis penulisan riset 
kesehatan. Yogyakarta: Graha Ilmu.

Sugiyono. (2012). Metode penelitian kuantitatif kualitatif dan $r \quad \&$ d.Bandung: Alfabeta.

Sujarweni, w. (2014). Metodologi penelitian

keperawatan. Yogyakarta: Gava Media.

Sumantri, a. (2011).Metodologi penelitian kesehatan.Jakarta: Kencana Penada Media Group.

Syamsuddin et al.(2015).Pedoman praktis metode penelitian internal.Ponorogo: CV. Wade Group.

Tola, b., \& Immanuel, n. 1 . (2015).Dukungan sosial dan kepatuhan minum obat pada pasien skizofrenia rawat jalan. Jurnal penelitian dan pengukuran psikologi.

WHO. (2017).Division of mental health and prevention of substance abuse schizophrenia and public health.Switzerland: Geneva.

Widiastutik, w., Winarni, i., \& Lestari, r. (2016).Dinamika resilinence keluarga penderita skizofrenia dengan kekambuhan. the indonesian journal of health science.

Wijayanti, a., \& Puspitosari, w. a. (2014). Hubungan onset usia dengan kualitas hidup pensderita skizofrenia di wilayah kerja puskesmas kasihan ii bantul Yogyakarta. Mutiara Medika.

Yosep, h. i., \& Sutini, t.(2014). Buku ajar keperawatan jiwa dan advance mental health nursing.Bandung: PT. Refika Aditama.

Yuliantika, Jumaini, \& Sabrianan, f. (2012). Faktor-faktor yang mempengaruhi kepatuhan minum obat pada pasien skizofrenia.

Yusuf, a., pk, r. f., \& Nihayati, h. e. (2015). Buku ajar keperawatan kesehatan jiwa.Jakarta Selatan : Salemba Medika. 
Tabel 1

Karakteristik Responden Pada Menurut Jenis Kelamin, Pendidikan Terakhir, Pekerjaan

\begin{tabular}{lcc}
\hline \multicolumn{1}{c}{ Karakteristik } & f & $\%$ \\
\hline Jenis Kelamin & 40 & 70.2 \\
Laki-Laki & 17 & 29.8 \\
Perempuan & & \\
Pendidikan Terakhir & 34 & 59.6 \\
Dasar & 18 & 31.6 \\
Menengah & 5 & 8.8 \\
Tinggi & & \\
Pekerjaan & 3 & 5.3 \\
PNS & 4 & 7.0 \\
Wiraswasta & 7 & 12.3 \\
Ibu Rumah Tangga & 35 & 61.4 \\
Petani & 8 & 14.0 \\
Tidak Bekerja & 57 & 100.0 \\
\hline \multicolumn{1}{r}{ Total } &
\end{tabular}


Table 2

Distribusi Frekuensi Responden Berdasarkan Umur, Dukungan Keluarga, Kepatuhan Minum Obat, Dengan Kekambuhan Pada Pasien Skizofrenia

\begin{tabular}{llcc}
\hline Variabel & \multicolumn{1}{c}{ kriteria } & f & \% \\
\hline - Umur & Remaja & 9 & 15.8 \\
& Dewasa & & \\
& Lansia & 22 & 38.6 \\
Total & & 26 & 45.6 \\
- Dukungan Keluarga & Mendukung & $\mathbf{5 7}$ & $\mathbf{1 0 0 . 0}$ \\
& Tidak Mendukung & 23 & 40,4 \\
Total & & 34 & 59,6 \\
- Kepatuhan Minum & Patuh & $\mathbf{5 7}$ & $\mathbf{1 0 0 . 0}$ \\
& & 22 & 38,6 \\
Obat & Tidak Patuh & 35 & 61,4 \\
& & $\mathbf{5 7}$ & $\mathbf{1 0 0 . 0}$ \\
Total & Kambuh & 49 & 86.0 \\
Kekambuhan & Tidak Kambuh & 8 & 14,0 \\
& & $\mathbf{5 7}$ & $\mathbf{1 0 0 . 0}$ \\
\hline
\end{tabular}


Tabel 3

Analisis Hubungan Umur, Dukungan Keluarga, dan Kepatuhan Minum Obat dengan Kekambuhan pada Pasien Skizofrenia

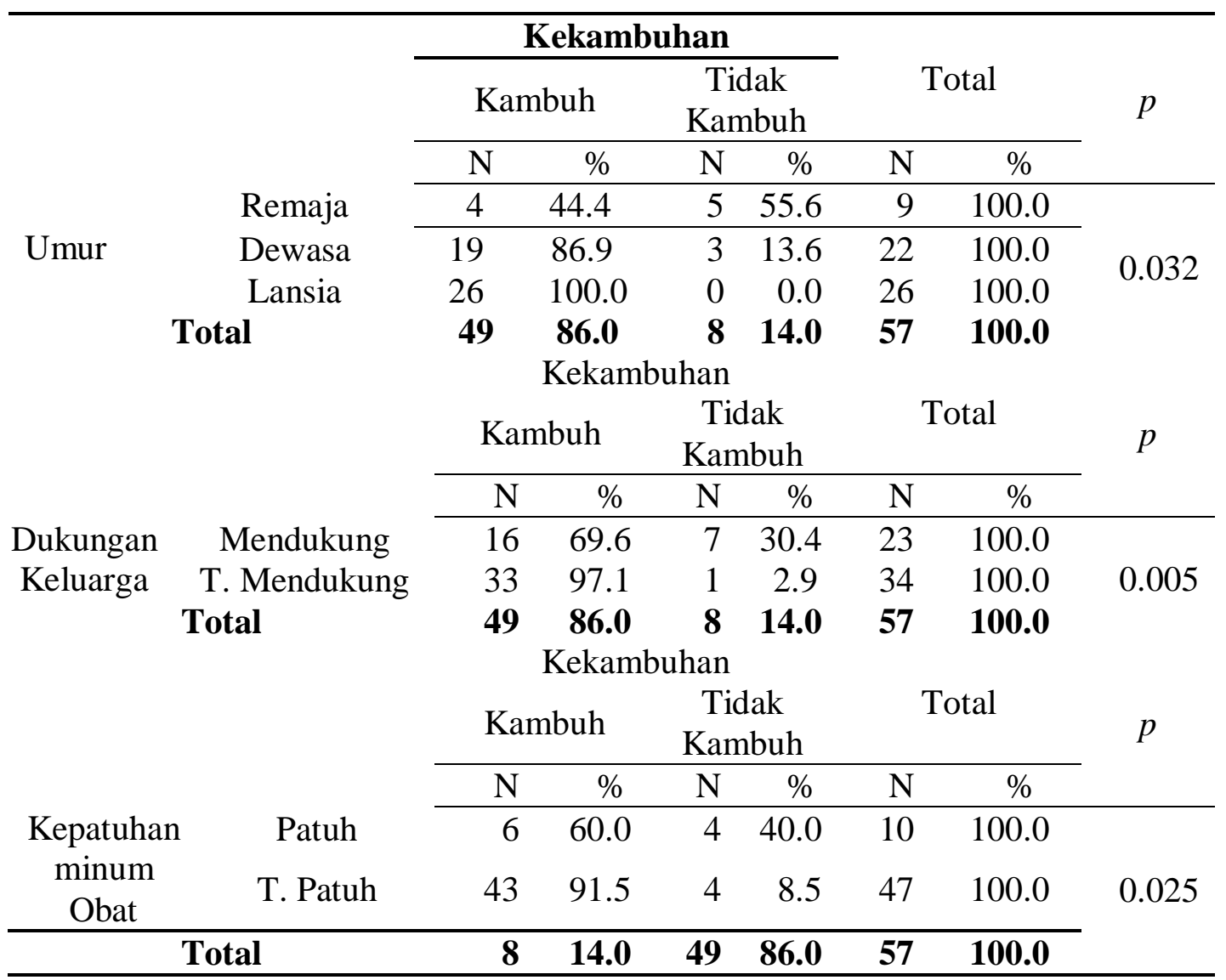

